Cakrawala Dini: Jurnal Pendidikan Anak Usia Dini | p-ISSN 2087-I317 | e-ISSN 2621-8321

Vol. I2. No.2 November 2021 | Hal I07-124

\title{
LOCAL WISDOM IN LARO NG LAHI AS FOUNDATION IN GAME- BASED PEDAGOGY
}

\author{
Roel V. Avila ${ }^{1}$ \\ ${ }^{1}$ Professor, Philippine Normal University South Luzon
}

\begin{abstract}
Filipino traditional games (Laro $n g$ Lahi) are reflective of the lifestyle of a locality and form part of significant national heritage. Albeit modern technology seems to challenge the existence of Laro ng Lahi, these traditional games can actually be transformed to adapt the present demands of the cyberspace. Employing the hermeneutic phenomenology and educational research \& development, the author paired the past investigations with his observations though the use of Hermeneutic Cycle as guide. Data obtained from the online survey accomplished by thirty-one (31) pre-service teachers (Generation $Z$, selected using the purposive sampling) provided connection between the online documents and the local practices and lived experiences of the respondents. Respondents are still familiar with piko (taplak gunung), agawan kuta (bentengan), and tubigan (gobak sodor) since they played such games before and they were aware of the the Laro ng Lahi benefits. Thus, they preferred to have Laro ng Lahi as activity tools in school subjects, and to convert academic knowledge and skills into learning course lessons. Upon finalizing the mechanics of each of the three Filipino traditional games, and the data provided by the respondents, the researcher conceptualized the game-based pedagogy and developed lessons using the local wisdom as the basis.
\end{abstract}

Keyword: local wisdom, traditional games, laro ng lahi, foundational basis, game-based pedagogy

\begin{abstract}
Abstrak: Permainan tradisional Filipina (Laro ng Lahi) merefleksikan gaya hidup suatu daerah dan merupakan bagian dari warisan nasional yang signifikan. Meski teknologi modern seolah menantang keberadaan Laro ng Lahi, permainan tradisional ini sebenarnya dapat ditransformasikan untuk mengadaptasi tuntutan dunia maya saat ini. Tujuan penelitian ini adalah mengembangkan pelajaran dari kearifan lokal yang digali dari permainan tradisional lokal. Metode yang digunakan yaitu fenomenologi hermeneutik dan R\&D, penulis memasangkan penyelidikan masa lalu dengan pengamatannya melalui penggunaan Siklus Hermeneutik sebagai panduan. Data yang diperoleh dari survei online yang dilakukan oleh tiga puluh satu (31) guru pra-jabatan menyediakan hubungan antara dokumen online dan praktik lokal dan pengalaman langsung responden. Temuan: Responden masih mengenal piko (taplak gunung), agawan kuta (bentengan), dan tubigan (gobak sodor) sejak mereka memainkan permainan tersebut sebelumnya dan mereka mengetahui manfaat Laro ng Lahi. Oleh karena itu, mereka lebih memilih Laro ng Lahi sebagai alat aktivitas dalam mata pelajaran sekolah, dan untuk mengubah pengetahuan dan keterampilan akademik menjadi pelajaran kursus dalam pembelajaran. Kesimpulan: Setelah menyelesaikan mekanisme masing-masing dari tiga permainan tradisional Filipina, dan data yang diberikan oleh responden, peneliti membuat konsep pedagogi berbasis permainan dan mengembangkan pelajaran dengan menggunakan kearifan lokal sebagai dasar.
\end{abstract}

Kata Kunci: Kearifan lokal, Permainan tradisional, laro ng lahi, basis dasar, Permainan berbasis pedagogik

\footnotetext{
' Philippine Normal University South Luzon, Email: pnusl.avila.rv回gmail.com
} 


\section{INTRODUCTION}

1. Background of the study

Stuck on their gadgets that cause the decline of their engagement in physical activities offered by traditional games or Laro $n g$ Lahi as Filipinos call them (Aguado, 2012), the children rarely play traditional games due to the advancement of technology (Bakar, et al., 2008; Estole, 2018; Miller \& Kuhaneck, 2008). Thus, UN encourages each country to preserve its cultural treasure (UNESCO, 2004).

Traditional games can still be preserved (Khan, et al., 2018) by employing continual engagement in the respective houses and integrating such in the classrooms (Prestoza, et al., 2020) by using ICT so that the new generations can understand (unesco.org, 2015).

The problem lies on the failure of the kids of Generation Z (Cobanoglul, Tagrikulu, \& Gul, 2018) to get health benefits provided by the traditional games (WHO, 2018) which are beneficial to a child's growth and development, cultural values and teaching practices (Kun, \& Mat Nayan, 2018; Prestoza, et al., 2020). Laro $n g$ Lahi is an escape for a stressful day, gives happiness to minds, and improves health (Prakash, 2012). All these show that engagement in traditional games is highly beneficial. There has to be some ways on how to preserve these indigenous games to suit the characteristics of the new generation.

The researcher decided to engage in extracting the local wisdom in Laro $n g$ Lahi as basic foundation in developing game-based pedagogy

\section{Objectives of the Study}

To present, discuss, and extract local wisdom from the select Philippine traditional games to come up with the formal statement on their significance as foundational basis in developing gamebased pedagogy.

a. Which among the given Philippine traditional games such as piko (taplak gunung), agawan kuta (bentengan), and tubigan (gobak sodor) the preservice teachers are familiar with?

b. Which of the given Filipino traditional games have they experienced playing?

c. Do the respondents' agree on the benefits the Filipino traditional games provide?

d. Do the pre-service teachers prefer to have Filipino traditional games as activity tools in school subjects?

e. Do the pre-service teachers agree to convert academic knowledge and skills gained through Laro ng Lahi into learning course lessons?

f. Which among the given Filipino traditional games are the respondents' favorite game?

g. What are the reasons why the respondents picked their respective favorite Laro ng Lahi?

h. What local wisdom can serve as bases in the development of game-based pedagogy?

\section{Scope and Limitation}

This investigation covers the Filipino Traditional Games or Laro ng Lahi and the latent local wisdom therein in the light of Filipino culture to serve as foundational basis of developing a gamebased pedagogy aimed at enhancing academic knowledge and skills. Due to pandemic, the data were gathered through online survey instrument accomplished by select pre-service teachers. Only three Laro ng Lahi, namely piko, agawan kuta, and tubigan were selected for the sake of focus and brevity.

\section{METHODOLOGY}

\section{Researach Design}

The author employed the hermeneutic phenomenology based on the existing documents which are paired with the author's observations (Mays \& Brown, 1972; Kneller, 1984), and the participants' lived experiences. Employing the Hermeneutic Cycle, the author engaged in 1) Reading and viewing 
of the Documents; 2) Reflective Writing; and 3) Interpreting (Kafle, 2011) or explicitation of data. Afterwards, the researcher used Borg and Gall's (2003) educational research and development $(\mathrm{R} \& \mathrm{D})$ in developing game-based pedagogy. It was tested during the Summer Program 2021 international conference hosted by Universitas Pendidikan Indonesia on September 1-11, 2021.

2. Participants

Data obtained from the online survey accomplished by thirty-one (31) pre-service teachers provided connection between the online documents and the local practices and lived experiences of the respondents. Being members of the Generation Z (and students of Foreign Language), they were selected using the purposive sampling based on the geographical location of their home municipalities.

3. Research Instrument

Modifying Kun and Mat Nayan's (2018) survey questions, the researcher contextualized the instrument and supported each item with related literature. The researcher used descriptive coding using the thematic analysis by identifying, analyzing, and interpreting patterns of meaning within the qualitative data as similarities and differences of responses are highlighted (Brenowitz \& Tuttle, 2003; Hermans, et al., 2008; Hu, et al., 2003; King, 2004)

4. Development of Course Lessons based on Laro ng Lahi

Upon finalizing the mechanics of each of the three Filipino traditional games, and the data provided by the respondents, the researcher conceptualized the game-based pedagogy and developed lessons using the local wisdom as the basis.

\section{RESULTS AND DISCUSSION}

Familiarity with the Select Laro ng Lahi. No respondents are not familiar with piko, agawan base, and tubigan.

1. Have you ever heard about the Filipino traditional games such as PIKO, AGAWAN BASE, and TUBIGAN?

31 responses

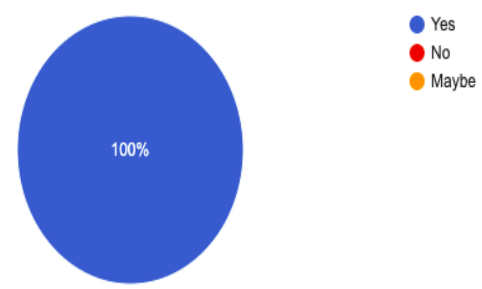

Figure 1. Pre-service Teachers' Familiarity with piko (taplak gunung), agawan kuta (bentengan), and tubigan (gobak sodor)

Playing the games means familiarity with such games. Compared to the study of Asuncion (2019) which revealed that 56.66 percent of research participants still play traditional Filipino games, all respondents in the present study provided a much higher percentage (100\%), proving the claim of Prestoza, et al. (2020) that Laro ng Lahi are still played by children despite their access to advanced technologies. Prestoza, et al., (2020) further expounded that the elementary school teachers usually observe these Laro ng Lahi that are still played by pupils: Tumbang Preso, Sipa, Patintero, Tagu-Taguan, Chinese Garter, Sungka, Luksong Tinik, Luksong Baka, Holen,

Tug of War, Agawang Sisiw, BumBum Lata, Agawan ng Panyo, Agawan ng Base, and Siyato. 
Experienced Playing Laro ng Lahi.

2. Have you ever played any Filipino traditional children's game before? 31 responses

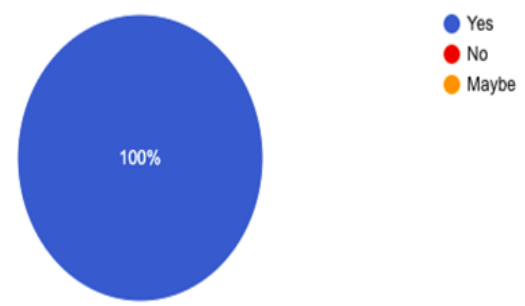

Figure 2. Experiences in Playing the Select Laro ng Lahi

All respondents experienced playing the select games. People value their experiences because they were able to connect the old generation to them (young generation), socialize with and create sense of togetherness, integrate friends and families in workplace, neighborhood, and generations, and open up the mind to diverse perspectives (Khan, et al., 2018). Playing the games of the old generation by the new generation is cultural preservation that needs scaffolding. Despite being members of Generation Z, the respondents have both the technological expertise and physical activeness by playing traditional games, contradicting the claim of Cobanoglul, et al., (2018). However, this gap between Generation $\mathrm{X}$ and Generation $\mathrm{Z}$ is continuously widening due to the gadgets the latter have.

Benefits on Body and Brain Gained through Laro ng Lahi

3. Do Filipino traditional children's games help to exercise your body and brain? 31 responses

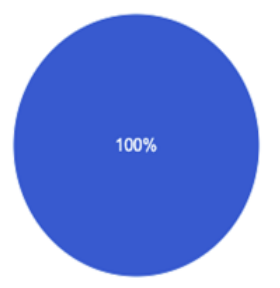

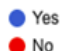

Maybe
Figure 3.1 Benefits on body and brain gained through Laro ng Lahi

The respondents showed 100\% agreement to the specified benefits. Today's kids fail to get health benefits provided by the traditional games. In order to attain the cardiorespiratory and muscular fitness, bone health, and cardiovascular and metabolic health biomarkers, child's growth and development, cultural values and teaching practices as benefits of playing traditional games (WHO, 2018; Kun, \& Mat Nayan, 2018) children must be guided to accumulate at least 60 minutes of physical activity daily. Playing the Laro ng Lahi develops motor skills, body coordination, exercise locomotor, apply skill-related activities, and enhance mental capacity (Prestoza, et al., 2020), besides, Laro ng Lahi is an escape for a stressful day, gives happiness to minds, and improves health (Prakash, 2012).

Benefits from Laro ng Lahi on Personal Discipline and Socialization

4. Do you learn about personal discipline and socialization through these traditional games? 31 responses

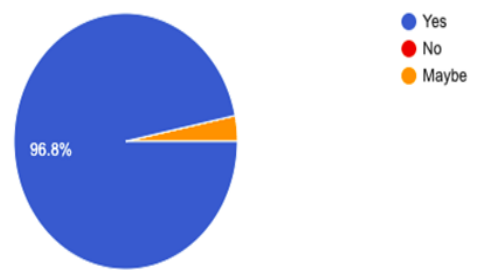

Figure 3.2. Benefits on personal discipline and socialization gained through Laro ng Lahi

Personal discipline and socialization are learned by the $96.8 \%$ of the respondents. Traditional games, as talking games, are capable of improving students' communication and collaborative skills (Suhaebah, 2019; Kolb, 1984). As children are entertained in their engagement in games, cognitive (Piaget, 1962; Vygotsky, 1966) and psychosocial developments (Elkind, 2007; Erikson, 
1950) occur. Playing game is an indispensable part of children's development (Foley, 2008) and is the springboard to the attainment of some universal values (Aypay, 2016).

\section{Benefits from Laro ng Lahi on Building} Team Spirit

5. Do you learn about team spirit through the Laro ng Lahi?

31 responses

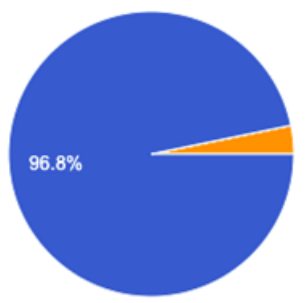

Figure 3.3. Team spirit gained through Laro ng Lahi

Almost all (96\%) of the respondents agreed that Laro ng Lahi enhance team spirit. Studies have shown that traditional games can play a significant role in children's growth and development, which help to improve the basic skills of children, such as physical health, thinking skills, interpersonal and social skills (Saputra, 2017; Maryani, 2009). Laro ng Lahi establishes children's selfconfidence, positive attitude, sportsmanship, camaraderie, and friendship (Prestoza, et al., 2020). By playing, socialization skills are honed and the concept of "others" as different from their selves is discovered.

\section{Laro ng Lahi as Activity Tools in School} Subjects.

6. Would you like to have Filipino traditional children's games as activity tools in any school subject?

31 responses
Figure 4. Preference to have Filipino traditional children's games as activity tools in any school subject.

Respondents wanted to have Filipino traditional games as activity tools in any school subject (90.3\%). Not connecting the games played outside by the learners to the lessons inside the classroom contributes to the boredom which they experience. If the claim of Aguado (2012) is true that traditional Filipino street games are alive in the Philippines, the teachers have to utilize them for increased motivation. While members of Generation $\mathrm{Z}$ are still into traditional games (Asuncion, 2019; Khan, et al., 2018), the teachers can grasp the opportunity to use them (Prestoza, et al., 2020) even in teaching values (Aypay, 2016), for the sake of their happiness and health (Elkind, 2007), by helping to improve the children's basic abilities (Saputra \& Ekawati, 2017), by tapping the media (Kun \& May Nayan, 2018), by preserving them (Estole, 2018; Magna Kultura, 2012), by knowing the kids' play preferences (Miller \& Kuhaneck, 2008), and to develop learners' communication and collaborative skills (Suhaebah, 2019). Related literature and studies strongly support the idea of making traditional games as activity tools in teaching school subjects.

Conversion of Academic Knowledge and Skills Gained through the Laro ng Lahi into Learning Course Lessons

7. Can academic knowledge and skills gained through the Laro $\mathrm{ng}$ Lahi be converted into learning course lessons?

31 responses

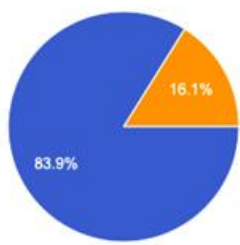

Yes Maybe

Figure 5. Preference on the conversion of knowledge and skills gained through Laro ng Lahi into learning course lessons. 
A big chunk of responses $(83.9 \%)$ supports the idea of converting knowledge and skills gained through Laro ng Lahi into learning course lessons. The other chunk (16.1\%) implies questioning how it can be done. Designing and validating Laro ng Lahi as game-based academic activity are the foci of some researchers (Del Carmen, et al., 2015). Morales (2017) explored indigenous games as basis in Physics activities, Suhaebah (2019) in teaching Social Studies, conforming to UNESCO (2018) in its desire to mobilize countries to incorporate traditional children's games in classrooms, which Estole (2018) followed by recommending for Laro ng Lahi inclusion to DepEd programs.
Respondents' Favorite Games

8. Among PIKO, AGAWAN BASE, and TUBIGAN which used to be your favorite game? 31 responses

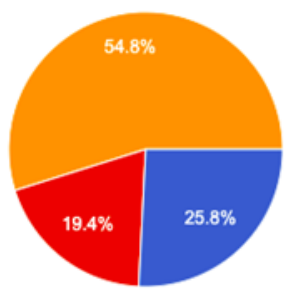

- agawan BASE TUBIGAN

Figure 6. Respondents' favorite Filipino traditional game

Respondents' favorite games as to rank are Tubigan (54.8\%), Piko (25.8\%), and Agawan Base (19.4\%). Owing to the nature of Tubigan - collaborative, exciting, challenging, gender-fair, and movement-based, Tubigan becomes the favorite game. Miller and Kuhaneck (2008) stressed the importance of considering the perceptions of the players as well as their play preferences. It is a sound action of a teacher to always ask for students' game preferences. 


\begin{tabular}{ll}
\hline FAVORITE LARO NG LAHI & REASON (IN THEMES) \\
\hline PIKO & - memories with friends and cousins \\
& - does not consume much energy \\
& - simplicity of the game \\
& - players' persistence \\
& - helps body to be active \\
& - mind-body coordination \\
& - enhances discipline \\
& - requires focus \\
& - a form of body exercise \\
& - enhances leadership skills \\
& - promotes sportsmanship \\
& - helps think of tactics \\
& - promotes team spirit (camaraderie) \\
& - can involve more players to have more \\
& - fun \\
\hline AGAWAN BASE (KUTA) & - develops communicative skills \\
& - develops personality \\
& - helps possess strategic thinking \\
& - fun and challenging \\
& - exciting \\
& - develops alertness \\
& - requires team coordination \\
& - improves socialization skills \\
& - allows creativity \\
& - often played \\
& - improves cognitive and psychomotor \\
& - skills \\
& - Requires agility and flexibility \\
& - player needs to think fast and be alert \\
& every time \\
\hline TUBIGAN (PATINTERO) & \\
\hline & \\
&
\end{tabular}

Table 1 contains the words of the respondents as answers to the question What are your reasons for picking the favorite Laro ng Lahi? The answers were reduced into themes.

Piko, Agawan Base, and Tubigan are favorite games because they are not much physically demanding; they do not require more resources (especially
Tubigan); they are entertaining; they reflect local culture; they are in tune with the existing living styles of the locality (Khan, et al., 2018). It is consequently recommended that these three traditional games be the subjects of game-based pedagogy. 
Table 2. Local Wisdom in Piko as Foundational Basis in the Development of Game-based Pedagogy

\begin{tabular}{|c|c|c|c|}
\hline $\begin{array}{l}\text { GLOBAL } \\
\text { GAME }\end{array}$ & LARO NG LAHI & LOCAL WISDOM & $\begin{array}{l}\text { GAME-BASED } \\
\text { PEDAGOGY }\end{array}$ \\
\hline Hopscotch & PIKO & Homestead & $\begin{array}{l}\text { Learning } \quad \text { New } \\
\text { Language }\end{array}$ \\
\hline $\begin{array}{l}\text { Game's } \\
\text { Objective }\end{array}$ & Owning each box & Occupying field & $\begin{array}{l}\text { To win each } \\
\text { category }\end{array}$ \\
\hline Players & $\begin{array}{l}\text { Individual (M or F) } \\
\text { Ideal Number }=5\end{array}$ & $\begin{array}{lll}\text { Individual } & \text { Talent } \quad \& \\
\text { Strategy } & & \end{array}$ & Reviewing Lessons \\
\hline $\begin{array}{l}\text { Materials } \\
\text { Needed: } \\
\text { Clearing } \\
\text { tool }\end{array}$ & $\begin{array}{l}\text { Plain ground (tiled, } \\
\text { cemented, soil) } \\
\text { Line markers. } \\
\text { Chalk, tape, string, } \\
\text { Pamato (Pucks) } \\
\text { piece of jar, slipper. }\end{array}$ & $\begin{array}{l}\text { Unoccupied field } \\
\text { Land markers }\end{array}$ & $\begin{array}{l}\text { Module } \\
\text { Powerpoint Slides } \\
\text { Access to Virtual } \\
\text { Room }\end{array}$ \\
\hline Rules: & $\begin{array}{l}\text { 1.Join the manohan } \\
\text { 2. Respect succession of } \\
\text { turns } \\
\text { 3. Pamato must be } \\
\text { identical in size } \\
\text { 4. No stepping on the } \\
\text { line } \\
\text { 5. Don't touch the } \\
\text { ground } \\
\text { 6. Don't step on other's } \\
\text { house. } \\
\text { 7. Wait for your turn }\end{array}$ & $\begin{array}{l}\text { 1. Daig ng maagap ang } \\
\text { masipag (Being early bests } \\
\text { being hardworking) } \\
\text { 2. Concept of "Nauna" (As } \\
\text { in ordinal position among } \\
\text { siblings) } \\
\text { 3. Use the right tool } \\
\text { 4. Respect ecosystem. } \\
\text { 5. No unnecessary cutting } \\
\text { of trees } \\
\text { 6. Respect private property } \\
\text { 7. There is learning in } \\
\text { waiting by observing. }\end{array}$ & $\begin{array}{l}\text { 1. First to answer } \\
\text { question } \\
\text { 2. Type on the chat } \\
\text { box } \\
\text { No use of translator } \\
\text { Don't answer } \\
\text { other's Q }\end{array}$ \\
\hline $\begin{array}{l}\text { How to } \\
\text { play the } \\
\text { game: }\end{array}$ & $\begin{array}{l}\text { 1. Join the manohan. } \\
\text { 2.Wait for your turn } \\
\text { 3. Throw your Pamato } \\
\text { on Box 1; } \\
\text { Hop to Box 2; jump to } \\
\text { Boxes } 3 \text { \& 4; Hop to } \\
\text { Box 5; jump to Boxes } 6 \\
\& \text { 7; Hop to Box } 8 \text { and } \\
\text { turn around. Retrace } \\
\text { your path; reach for } \\
\text { Pamato; skip Box 1; } \\
\text { land on Starting Line; } \\
\text { Turn back on Playing } \\
\text { field; gently throw } \\
\text { pamato; mark your } \\
\text { house where pamato } \\
\text { landed; rest and wait for } \\
\text { Round 2. }\end{array}$ & $\begin{array}{l}\text { Concept of "Dayo" } \\
\text { Clearing the field the right } \\
\text { way } \\
\text { Nasa Dios ang awa, nasa } \\
\text { tao ang gawa } \\
\text { Throwing of pamato } \\
\text { (Gawa) } \\
\text { Where pamato landed } \\
\text { (Awa) } \\
\text { Resting (Ginhawa) } \\
\text { Waiting (Pagbibigay-daan) } \\
\text { Balik-bayan = Bayani } \\
\text { Field is owned by worthy } \\
\text { owner Determining the best } \\
\text { caretaker Owned by its } \\
\text { tiller }\end{array}$ & $\begin{array}{l}\text { Recognized } \\
\text { Answer each Q } \\
\text { correctly Pass } \\
\text { through all levels } \\
\text { Reserve appeal } \\
\text { Claim the selected } \\
\text { Category }\end{array}$ \\
\hline
\end{tabular}

Table 2 shows four columns with the headings Global Game, Laro ng Lahi, Local Wisdom, and Game-based
Pedagogy. Piko has a resemblance to the global game called Hopschotch. Obviously, hopscotch is cutting a large 
area into small pieces (Whiteman, 2005). To apply its basic concept locally, Piko could mean occupying a certain field out of a bigger one according to the specifications of the laws on agrarian reform and agriculture.

There are bits of local wisdom involved in the process of occupying certain fields, such as "Daig ng maagap ang masipag!" (The early beat the hardworking!), ecocentrism (of animism by the pre-hispanic Philippines) over anthropocentrism (of Christianity by the Spanish conquistadores). The caretaker of a certain field becomes worthy only after considering local-wisdom-related principles, i.e. [1] Sa marunong magbungkal, ang lupa ay ibibigay (The land belongs to someone who tills it), [2] Asking permission before cutting down an old tree: Ilocanos utter "Bari Bari/Dika agunget pari/Ta pumukan kami/Iti pabakirda kami// (Do not feel bad my friend for we cut as we are ordered.); the Visayans believe that if they were to cut down the trees before they had induced the spirits to move away, something bad will happen to the whole family (Millington \& Maxfield, 1906); the Tagalogs used to utter these lines: Puno, puno, paghinga ay pigilin/ Pansumandali laang, ikaw ay aputulin/ Mula sa 'yong tuod, ikaw ay masupling/ (Tree, tree, hold your breath; I will momentarily cut you down; from your stump, you are expected to sprout.) (Avila, 2020). These are but two of the local wisdom which must be considered by a homesteader.

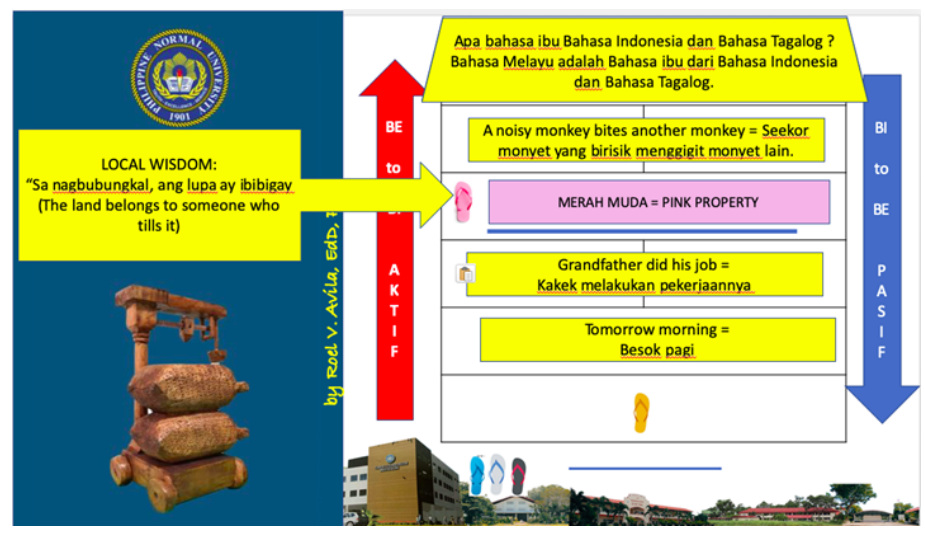

Figure 7. Sample slide on game-based pedagogy using Piko.

Table 3. Local Wisdom in Agawan Base as Foundational Basis in the Development of Game-based Pedagogy

\begin{tabular}{|c|c|c|c|}
\hline $\begin{array}{l}\text { GLOBAL } \\
\text { GAME }\end{array}$ & LARO NG LAHI & LOCAL WISDOM & $\begin{array}{l}\text { GAME-BASED } \\
\text { PEDAGOGY }\end{array}$ \\
\hline $\begin{array}{l}\text { Prisoner's } \\
\text { Base }\end{array}$ & Agawan Base & Agawan Kuta & Pangangayaw \\
\hline $\begin{array}{l}\text { Game's } \\
\text { Objective: }\end{array}$ & $\begin{array}{l}\text { Get the opponent's } \\
\text { flag }\end{array}$ & $\begin{array}{l}\text { 1. Pananamsam } \\
\text { 2. Paghihiganti } \\
\text { 3. Pamahiin } \\
\text { 4. Karangalan } \\
\end{array}$ & $\begin{array}{l}\text { Team Victory } \\
\text { Individual Victory }\end{array}$ \\
\hline Players: & $\begin{array}{l}\text { 1. Runner } \\
\text { 2. Strategist } \\
\text { 3. Bait } \\
\text { 4. Savior } \\
\text { 5. Sentinel } \\
\text { Agorang } 1 \\
\text { Agorang } 2 \\
\text { Agorang } 3\end{array}$ & $\begin{array}{l}\text { 1.Matulin (Quick) } \\
\text { 2.Maparaan (Creative) } \\
\text { 3.Maisog (Brave) } \\
\text { 4.Mapagkalinga } \\
\text { (Caring) } \\
\text { 5.Mapagmanman } \\
\text { (Observant) } \\
\text { Agorang } 1=\text { former } \\
\text { raha (raja) } \\
\text { Agorang } 2=\text { former } \\
\text { bagani (berani) }\end{array}$ & $\begin{array}{l}\text { 1. Fastest to translate; } \\
\text { 2. Finding ways how to } \\
\text { translate correctly; } \\
\text { 3. Volunteers when } \\
\text { nobody in the team } \\
\text { wants to answer; } \\
\text { 4. Provides help to the } \\
\text { recognized team mate; } \\
\text { 5. Looks for opponents } \\
\text { who attempt to cheat; } \\
\text { Agorang } 1 \text { = Supplies } \\
\text { sentences to translate; }\end{array}$ \\
\hline
\end{tabular}




\begin{tabular}{|c|c|c|c|}
\hline & & $\begin{array}{l}\text { Agorang } 3 \\
\text { babaylan/guro (guru) }\end{array}=$ & $\begin{array}{l}\text { heads in giving decisions } \\
\text { to issues; } \\
\text { Agorang } 2=\text { Proclaims } \\
\text { each decision; helps in the } \\
\text { analysis of each issue; } \\
\text { Agorang } 3=\text { Checks the } \\
\text { correctness of each } \\
\text { sentence. }\end{array}$ \\
\hline Materials: & $\begin{array}{l}\text { 1. Playing field at } \\
\text { least as big as a } \\
\text { basketball court } \\
\text { 2. Two posts } \\
\text { 3. Two flags }\end{array}$ & $\begin{array}{l}\text { 1. Banwa } \\
\text { 2. Puod } \\
\text { 3. Bandila }\end{array}$ & $\begin{array}{l}\text { Internet connection } \\
\text { Virtual Room } \\
\text { Chat box }\end{array}$ \\
\hline Rules: & $\begin{array}{l}\text { 1. Same number of } \\
\text { players } \\
\text { 2. Fresher player } \\
\text { defeats older } \\
\text { player } \\
\text { 3. Touching the post } \\
\text { = refreshed } \\
\text { 4. Plant the flag } \\
\text { beside the post } \\
\text { 5. Tag1 (tagged by } \\
\text { the enemy) = } \\
\text { captured } \\
\text { 6. Tag2 (tagged by } \\
\text { teammate) } \\
\text { refreshed = } \\
\text { 7. Tag3 (tagged by } \\
\text { teammate) saved } \\
\text { 8. Tag4 (tagged } \\
\text { again by enemy) = } \\
\text { recaptured as slave } \\
\text { 9. Slave can't be } \\
\text { saved th by } \\
\text { teammates } \\
\text { 10.Slave can serve as } \\
\text { spy to steal the } \\
\text { flag (opponent's } \\
\text { tag prevents the } \\
\text { slave) }\end{array}$ & $\begin{array}{l}\text { 1. Patas na } \\
\text { pagkakataon (equal } \\
\text { chance) } \\
\text { 2. Kabataan: Youth } \\
\text { over old age in war } \\
\text { 3. Pakikiugnay: } \\
\text { Constant } \\
\text { communication } \\
\text { with the group } \\
\text { 4. Bandila: Flag } \\
\text { represents the entire } \\
\text { tribe } \\
\text { 5. Pagkakabihag: } \\
\text { Captivity with } \\
\text { purpose is not to be } \\
\text { ashamed of. } \\
\text { 6. Pang-agdong: } \\
\text { Reinforcement } \\
\text { renews the goal } \\
\text { 7. Utang na Loob = } \\
\text { Life for life } \\
\text { 8. Muling Pagkabihag } \\
\text { = Recapture, with } \\
\text { purpose, is heroism. } \\
\text { 9. Ang taong walang } \\
\text { lululuning banig ay } \\
\text { hindi takot } \\
\text { mamatay } \\
\text { 10. Alipin ma'y may } \\
\text { silbi rin: A slave } \\
\text { can still help his } \\
\text { village. }\end{array}$ & $\begin{array}{l}\text { 1. Equal number of } \\
\text { questions and equal } \\
\text { level of difficulty } \\
\text { 2. Students present in the } \\
\text { virtual room are } \\
\text { prioritized } \\
\text { 3. Get assistance from } \\
\text { team members } \\
\text { 4. Flag is kept with utmost } \\
\text { care. Do not } \\
\text { underestimate the } \\
\text { importance of the } \\
\text { game. } \\
\text { 5. Providing wrong } \\
\text { translation is chance to } \\
\text { learn the right one. } \\
\text { 6. Listening to team } \\
\text { mate's help is precious. } \\
\text { 7. Team mate who helped } \\
\text { you translate should be } \\
\text { appreciated. } \\
\text { 8. Committing two errors } \\
\text { gives higher degree of } \\
\text { learning the right } \\
\text { answer. } \\
\text { 9. A student who used to } \\
\text { commit errors is not } \\
\text { anymore afraid to } \\
\text { commit another one. } \\
\text { 10.If a student does not } \\
\text { know how to translate, } \\
\text { s/he can still extend } \\
\text { assistance to the team. }\end{array}$ \\
\hline $\begin{array}{l}\text { How to } \\
\text { play the } \\
\text { game: }\end{array}$ & $\begin{array}{l}\text { 1. One player shall } \\
\text { get the total } \\
\text { number of } \\
\text { children present; }\end{array}$ & $\begin{array}{l}\text { 1. Importance of } \\
\text { census in each } \\
\text { barangay; }\end{array}$ & $\begin{array}{l}\text { 1. Finding out the number } \\
\text { of students who are } \\
\text { virtually present; }\end{array}$ \\
\hline
\end{tabular}




\begin{tabular}{|c|c|c|}
\hline 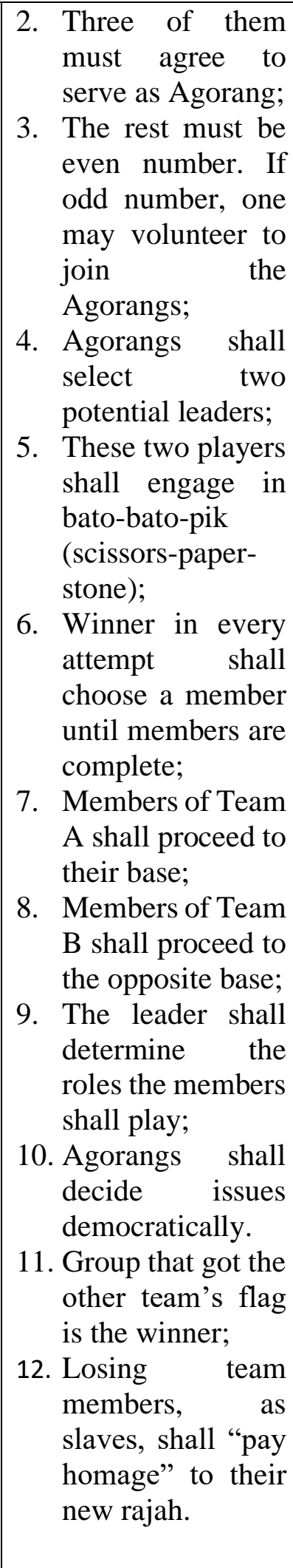 & $\begin{array}{l}\text { 2. The odd number of } \\
\text { Agorangs is ideal } \\
\text { since they rule by } \\
\text { majority vote; } \\
\text { three is better than } \\
\text { five; } \\
\text { 3. Even number is } \\
\text { divisible equally } \\
\text { by 2; } \\
\text { 4. Wise people know } \\
\text { who has the } \\
\text { potential to lead; } \\
\text { 5. Game of chance } \\
\text { elevates the issue } \\
\text { to Bathala to } \\
\text { decide justly; } \\
\text { 6. Leader is given the } \\
\text { freedom to choose; } \\
\text { 7. Base or kuta gives } \\
\text { occupants sense of } \\
\text { ownership and } \\
\text { responsibility; } \\
\text { 8. Attaching the flag } \\
\text { to the pole is } \\
\text { symbolic of their } \\
\text { common goal; } \\
\text { 9. There is no "weak" } \\
\text { member if the } \\
\text { leader knows their } \\
\text { varied talents; } \\
\text { 10. Agorangs or } \\
\text { Elders can give } \\
\text { wise counsels if } \\
\text { they do not have } \\
\text { personal interests; } \\
\text { 11. Formal declaration } \\
\text { of war agreement, } \\
\text { important; is } \\
\text { 12. Although war is } \\
\text { anchored on observed; } \\
\text { deception, word of } \\
\text { tonor, based on }\end{array}$ & $\begin{array}{l}\text { 2. Odd number is good; } \\
\text { even number can slide } \\
\text { to deadlock; } \\
\text { 3. Even number among } \\
\text { the students to form } \\
\text { two teams is good; } \\
\text { 4. Agorangs must have } \\
\text { noses for potential } \\
\text { student leaders; } \\
\text { 5. Every game has the G } \\
\text { factor; } \\
\text { 6. Leader's choice can } \\
\text { spell the difference; } \\
\text { 7. Grouping provides the } \\
\text { sense of } \\
\text { belongingness; } \\
\text { 8. Virtual flag of the } \\
\text { losing team must be } \\
\text { attached to the flag } \\
\text { pole of the winning } \\
\text { team; } \\
\text { 9. Translating sentences } \\
\text { is made easy by } \\
\text { pooling ideas together; } \\
\text { 10. How can the Agorangs } \\
\text { know the correct } \\
\text { translation if they lack } \\
\text { knowledge about it? } \\
\text { 11. Agreement to engage } \\
\text { in competition is } \\
\text { important; } \\
\text { 12. Losing with grace is } \\
\text { more important than } \\
\text { winning } \\
\text { deception;winner. }\end{array}$ \\
\hline
\end{tabular}

Table 3 presents the mechanics of the game, Agawan Kuta, with the local wisdom serving as basis in developing a game-based pedagogy. The Game's
Objective is to capture the base by getting the flag (called Pangangayaw in early Philippines where spoils of war, such as gold and animals, as well as some citizens 
to be enslaved). It can serve as basis of game-based pedagogy by limiting the game to negotiation where translation of sentences occur (in the case of Foreign Language course).

Players of Agawan Kuta, who, ideally, must have respective roles to play, ought to learn much from the war their game mimics particularly in terms of strategies. There is really truth in the old saying: "To the victor belongs the spoils of war" or in Filipino parlance: "Mga bihag at bulawan ay para sa mga nagtagumpay".

Each team consists of at least 5 members with the following characteristics: [1] Matulin (Quick), [2] Maparaan (Creative), [3] Maisog (Brave), [4] Mapagkalinga (Caring), and [5] Mapagmanman (Observant). In the Game-based Pedagogy, each Agorang has a clear role to fulfill: Agorang $1=$ Supplies sentences to translate; heads in giving decisions to issues; Agorang $2=$ Proclaims each decision; helps in the analysis of each issue; and Agorang $3=$ Checks the correctness of each sentence.

The concept of Pangangayaw (Invasion) has evolved at present: Pangingibang-bayan at paghahanap ng ginhawa (Villan \& Esquejo, 2021). In other words, Pangangayaw which is figuratively represented by Agawan Kuta (Prisoner's Base) may positively mean going abroad to get wealth, knowledge, skills, experiences, fame, etc. and coming back to the homeland. This is the concept of bayani or hero according to Salazar (2004).

As applied to game-based pedagogy, Agawan Kuta is attempt to win the game and go home with the "spoils of war" as the old Tagalog saying goes: "Mga bihag at bulawan ay para sa mga nagtagumpay" (To the victor belongs the spoils of war), meaning, if the course is Foreign Language, finishing the course by learning the language, that is, considering the rules of war (Lu, 2018) specifically safeguarding religious sites (UNAOC, 2019), and not destroying cultural heritage (Stone, 2020). Sentences have to be reflective of religious tolerance and other sensitive principles.

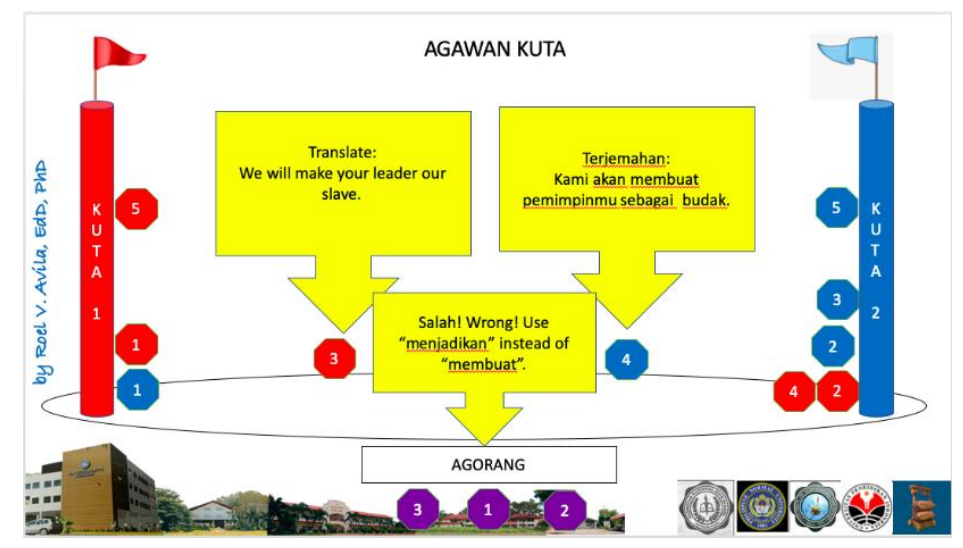

Figure 8. Graph on Agawan Kuta showing Q $\& \mathrm{~A}$ as judged by the Agorang

Table 4. Local Wisdom in Tubigan as Foundational Basis in the Development of Game-based Pedagogy

\begin{tabular}{|l|l|l|l|}
\hline $\begin{array}{l}\text { GLOBAL } \\
\text { GAME }\end{array}$ & \multicolumn{1}{|c|}{ LARO NG LAHI } & \multicolumn{1}{|c|}{ LOCAL WISDOM } & \multicolumn{1}{c|}{$\begin{array}{c}\text { GAME-BASED } \\
\text { PEDAGOGY }\end{array}$} \\
\hline $\begin{array}{l}\text { Block \& } \\
\text { Tag Game }\end{array}$ & Tubigan or Patintero & $\begin{array}{l}\text { Tago Nang Tago } \\
\text { (TNT) }\end{array}$ & Tubigan \\
\hline $\begin{array}{l}\text { Game's } \\
\text { Objective: }\end{array}$ & $\begin{array}{l}\text { One Team: to pass } \\
\text { through the guards back } \\
\text { and forth } \\
\begin{array}{l}\text { Other Team: to tag any } \\
\text { member of the Team } \\
\text { trying to pass through }\end{array}\end{array}$ & $\begin{array}{l}\text { 1.Staying illegally in } \\
\text { a foreign land } \\
\text { 2.Catching illegal } \\
\text { immigrants } \\
\text { Concept: Tagarito, } \\
\text { Dayo }\end{array}$ & $\begin{array}{l}\text { Surviving Interrogation by } \\
\text { using the language of } \\
\text { another group }\end{array}$ \\
\hline Players: & $\begin{array}{l}\text { 4 players each team } \\
\text { For One Team: }\end{array}$ & $\begin{array}{l}\text { Hiding, Feigning, } \\
\text { Collaborating, }\end{array}$ & $\begin{array}{l}\text { 4 members each team have } \\
\text { respective roles to fulfill }\end{array}$ \\
\hline
\end{tabular}




\begin{tabular}{|c|c|c|c|}
\hline & $\begin{array}{l}\text { Panguna: } \\
\text { guarding the first line } \\
\text { Pangalawa: Player } \\
\text { guarding the second } \\
\text { line } \\
\text { Pangatlo: Player } \\
\text { guarding the third line } \\
\text { Panggitna: Player } \\
\text { guarding the middle } \\
\text { line intersecting the } \\
\text { three lines } \\
\text { For Another Team: } \\
\text { Pang-uyo } \\
\text { Panggulo } \\
\text { Panglusot } \\
\text { Panggoyo }\end{array}$ & $\begin{array}{l}\text { Fooling, Deceiving, } \\
\text { Bribing, Escaping } \\
\text { Although war is } \\
\text { always anchored on } \\
\text { deception, there are } \\
\text { actions which must } \\
\text { be avoided, such as } \\
\text { destroying cultural } \\
\text { heritage, including } \\
\text { relics and images } \\
\text { considered holy. } \\
\text { War treaties } \\
\text { Fear of the } \\
\text { Umalagad (pantheon } \\
\text { of gods) }\end{array}$ & \\
\hline Materials: & $\begin{array}{l}\text { Playing field: tiled, } \\
\text { cemented or not } \\
\text { If tiled, masking tape is } \\
\text { used to form lines; If } \\
\text { cemented, chalk is } \\
\text { needed to draw lines; If } \\
\text { not, water is poured as } \\
\text { lines }\end{array}$ & $\begin{array}{l}\text { Banwa } \\
\text { Ibayong-dagat } \\
\text { Ibang lupain }\end{array}$ & $\begin{array}{l}\text { Internet connection } \\
\text { Virtual Room } \\
\text { Chat box }\end{array}$ \\
\hline Rules: & $\begin{array}{l}\text { 1. Equal number of } \\
\text { members } \\
\text { 2. Guard always stands } \\
\text { on the line. } \\
\text { 3. The only allowed } \\
\text { parts of the body to } \\
\text { legally tag an } \\
\text { immigrant are the } \\
\text { hands; } \\
\text { 4. Immigrants may use } \\
\text { their hands to } \\
\text { prevent the hands of } \\
\text { the guards from } \\
\text { tagging them; } \\
\text { 5. No immigrant shall } \\
\text { pass through using } \\
\text { the space outside the } \\
\text { boundary lines; } \\
\text { 6. Any immigrant may } \\
\text { negotiate with any } \\
\text { guard if the guard is } \\
\text { his/her friend. } \\
\text { 7. A guard who says } \\
\text { "pass" to an } \\
\text { immigrant is not }\end{array}$ & $\begin{array}{l}\text { 1. Equal chance } \\
\text { 2. A person outside } \\
\text { his/her territory } \\
\text { will render illegal } \\
\text { use of authority; } \\
\text { 3. A non- } \\
\text { commissioned } \\
\text { person cannot } \\
\text { usurp authority; } \\
\text { 4. The right to self- } \\
\text { preservation } \\
\text { 5. The space outside } \\
\text { the boundary line } \\
\text { belongs to } \\
\text { another country; } \\
\text { 6. Negotiation may } \\
\text { involve bribe or } \\
\text { relationships; } \\
\text { 7. "May isang } \\
\text { salita" (Palabra de } \\
\text { honor or word of } \\
\text { honor) }\end{array}$ & $\begin{array}{l}\text { 1. Two teams with equal } \\
\text { number of members; } \\
\text { 2. No question or answer } \\
\text { shall emanate from the } \\
\text { audience; } \\
\text { 3. A person who is not an } \\
\text { authority is not allowed } \\
\text { to interrogate a player; } \\
\text { 4. An interrogated player } \\
\text { has the right to clarify } \\
\text { each question; } \\
\text { 5. No player shall ask the } \\
\text { audience or } \\
\text { translator when the } \\
\text { game is played; } \\
\text { 6. Each player has the } \\
\text { right to negotiate or to } \\
\text { have mutual individual } \\
\text { agreement; } \\
\text { 7. "Pass" is only uttered } \\
\text { once every round by } \\
\text { only one member of the } \\
\text { concerned team. }\end{array}$ \\
\hline
\end{tabular}




\begin{tabular}{|c|c|c|c|}
\hline & $\begin{array}{l}\text { allowed to tag his/her } \\
\text { friend. }\end{array}$ & & \\
\hline $\begin{array}{l}\text { How to } \\
\text { play the } \\
\text { game: }\end{array}$ & $\begin{array}{l}\text { 1. Two teams with four } \\
\text { members each; } \\
\text { 2. Toss coin will } \\
\text { determine which } \\
\text { team will serve as IT. } \\
\text { 3. Team A (as IT), will } \\
\text { position themselves } \\
\text { sentinel guarding } \\
\text { each line (First Liner, } \\
\text { Second Liner, Third } \\
\text { Liner, and Middle } \\
\text { Liner) } \\
\text { 4. The IT Team shall } \\
\text { prevent the opposing } \\
\text { team by tagging each } \\
\text { player of the } \\
\text { opposing team to } \\
\text { cross each line and } \\
\text { come be } \\
\text { successfully } \\
\text { 5. Any member of the } \\
\text { opposing team that } \\
\text { successfully returned } \\
\text { to the starting line } \\
\text { brings a score. } \\
\text { 6. All members of } \\
\text { Team B shall again } \\
\text { position themselves } \\
\text { in the starting line to } \\
\text { try to repeat the } \\
\text { journey. } \\
\text { 7. If any member of } \\
\text { Team B is tagged } \\
\text { legally, Team B shall } \\
\text { become the IT and } \\
\text { Team A shall cross } \\
\text { the lines this time. } \\
\text { 8. Winner is decided by } \\
\text { scores according to } \\
\text { the agreed number of } \\
\text { rounds. }\end{array}$ & 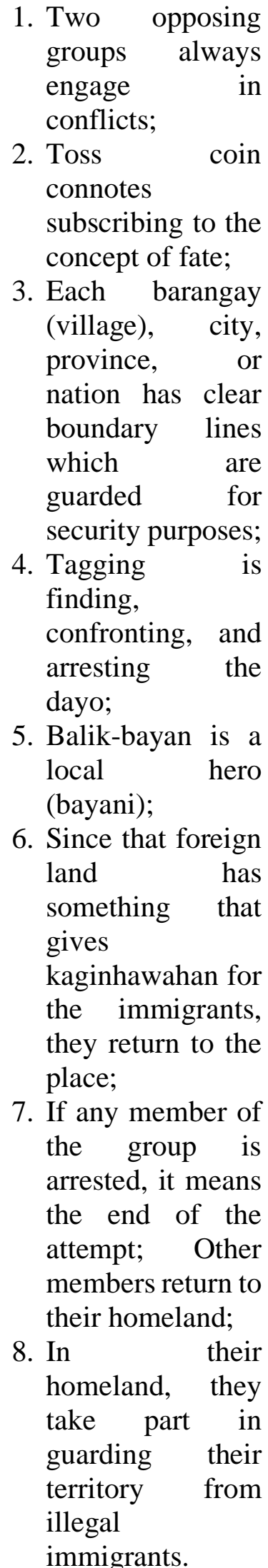 & $\begin{array}{l}\text { 1. Two teams with four } \\
\text { members each } \\
\text { 2. Toss coin to determine } \\
\text { the IT Team; } \\
\text { 3. Each line stores } \\
\text { questions for } \\
\text { interrogation; } \\
\text { 4. Finding one player, the } \\
\text { guard (using his } \\
\text { Team's language) } \\
\text { confronts him/her by } \\
\text { asking questions to } \\
\text { prove the one } \\
\text { confronted is an illegal } \\
\text { alien; in in is not } \\
\text { 5. If the one asked is able } \\
\text { to answer in that } \\
\text { language (it is not } \\
\text { his/her native tongue) is } \\
\text { given permission to } \\
\text { pass through; } \\
\text { 6. Virtually, one member } \\
\text { of Team A confronts } \\
\text { one member of Team B } \\
\text { (one-on-one) in going } \\
\text { forth. In going back, } \\
\text { each guard shall } \\
\text { confront a different } \\
\text { immigrant. } \\
\text { 7. Any member of the } \\
\text { group which gives a } \\
\text { wrong answer signals } \\
\text { the end of the Team's } \\
\text { journey without a } \\
\text { score; the } \\
\text { 8. As former immigrants } \\
\text { return home, they will } \\
\text { use their native } \\
\text { language to interrogate } \\
\text { members of } \\
\text { opposing team. }\end{array}$ \\
\hline
\end{tabular}


Table 4 presents the mechanics of Tubigan and the metaphorized local wisdom as basis of developing gamebased pedagogy. The mechanics enumerates the materials needed and the steps in playing Tubigan. As metaphorized, Tubigan taps the existing local wisdom, such as the concepts: tagarito (citizen), dayo (foreigner), balikbayan (return to country), kaginhawahan (comfort), Tago Nang Tago (hiding and escaping from authorities), and karapatang mabuhay (right to self-preservation).

Developing a pedagogy based on Tubigan best fits interrogations using the atmosphere of "immigrant-immigration officer" interaction

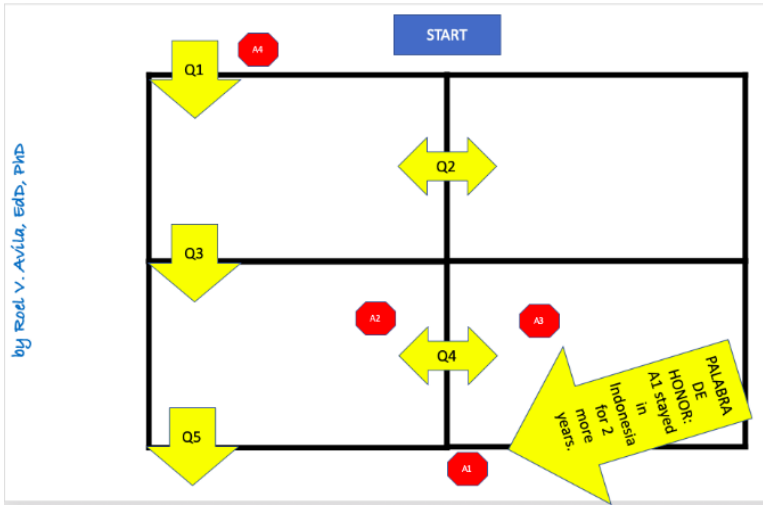

Figure 9.1. Graph showing the Filipino value Palabra de Honor in Tubigan

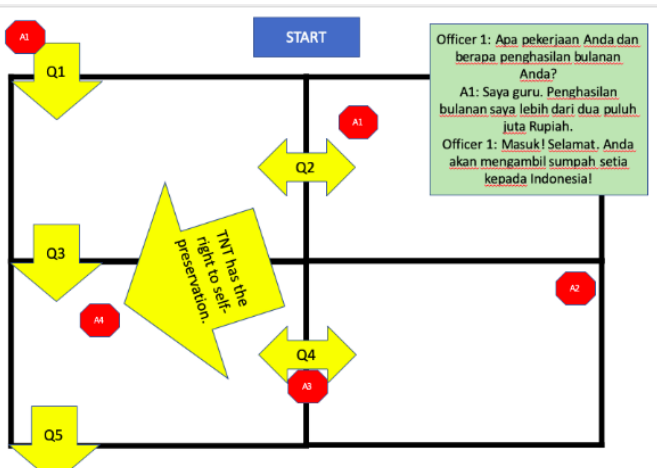

Figure 9.2. Graph showing a TNT and a player trying to cross the last line.

\section{CONCLUSION}

Since traditional games reflect the culture of a specific community, there is a need to preserve and to adapt such to the lifestyle of a locality, and modern technology can be of great help in the development of a game-based pedagogy that is anchored on local wisdom. This study used hermeneutic phenomenology and $\mathrm{R} \& \mathrm{D}$ on the beginning and last parts, respectively. Generation $\mathrm{Z}$ are still familiar with the Laro $n g$ Lahi by playing them at home and schools. They prefer Tubigan, Piko, and Agawan Kuta for several reasons, mostly, on being beneficial to brain and body, personal discipline and socialization, and building team spirit. They are amenable to the conversion of knowledge and skills gained through Laro ng Lahi into learning course lessons, thereby leading into a game-based pedagogy.

Respondents are still familiar with piko (taplak gunung), agawan kuta (bentengan), and tubigan (gobak sodor) since they played such games before and they were aware of the the Laro ng Lahi benefits. Thus, they preferred to have Laro ng Lahi as activity tools in school subjects, and to convert academic knowledge and skills into learning course lessons. Upon finalizing the mechanics of each of the three Filipino traditional games, and the data provided by the respondents, the researcher conceptualized the game-based pedagogy and developed lessons using the local wisdom as the basis.

Local Wisdom can be extracted from Laro ng Lahi to serve as foundational basis for game-based pedagogy. As advocate of Pedagogics of Indigenization, the researcher recommends to today's teachers to try this out to make learning fun and interesting.

\section{REFERENCES}

Aguado, D. (2012). The traditional Filipino street games are alive in the Philippines, Retrieved, November 22, 2013 from, http://dickieaguado.wordpress.co $\mathrm{m} / 2013 / 10 / 03 /$ the-traditional- 
filipino-street-games-are-alive-inthe-philippines/

Asuncion, J. (2019). The traditional Filipino games: Status check among Generation $Z$. https://www.researchgate.net/publ ication/336685466_THE_TRADI TIONAL_FILIPINO_GAMES_S TATUS_CHECK_AMONG_GE NERATION_Z/citation/download

Avila, R. V. (2020). Developing Bagwa as a reference book on nationalism integration in teaching social science courses at PNU South Luzon, Philippines. A dissertation presented to Sekolah Pascasarjana, Universitas Pendidikan, Indonesia.

Aypay, A. (2016). Investigating the role of traditional children's games in teaching ten universal values in Turkey. Eurasian Journal of Educational Research, 62, 283300, $\quad$ https://dx.doi.org/ 10.14689/ejer.2016.62.14

Bakar, A., Tuzun, H., \& Cagiltay, K. (2008). Students' opinions of educational computer game utilization: A social studies course case. In Prestoza, M. R., Paludipan, C. P., \& Abad, A. E. (2020). Perception of elementary school teachers on Laro ng Lahi in Quirino, Isabela. International Journal on Linguistics, Literature and Culture, 6(3), 1-8. Retrieved from

https://sloap.org/journals/index.ph p/ijllc/

Borg, W. D., \& Gall, M. D. (2003). Educational research: An Introduction. New York: Longman.

Brenowitz, N., \& Tuttle, C. R. (2003). Development and testing of a nutrition-teaching self-efficacy scale for elementary school teachers. Journal of nutrition education and behavior, 35(6), 308-311.
https://doi.org/10.1016/S14994046(06)60345-X

Cobanoglul, E. O., Tagrikulu, P., Gul, A. C. (2018). Games from Generation $\mathrm{X}$ to Generation Z. Universal Journal of Educational Research, 6(11): 2604-2623. Retrieved from http://www.hrpub.org.DOI: 10.13189/ujer.2018.061126

CRC (1990). Convention on the Rights of the Child text, from 2nd September 1990. Retrieved from https://www.unicef.org/childrights-convention/convention-text Del Carmen, M., Diano, F., \& Ole, A. (2015). Designing validated "Laro ng Lahi"-based activities in mechanics. Presented at the DLSU Research Congress 2015, March 2-4, 2015, at De La Salle University, Manila, Philippines.

Elkind, D. (2007). The Power of play: How spontaneous, imaginative activities lead to happier, healthier children. Cambridge, MA: Da Capo Press.

en.unesco.org (2015). Innovative ways to preserve and share knowledge about traditional games. https://en.unesco.org/news/innova tive ways-preserve-and-shareknowledge-about-traditionalgames/

Erikson, E. H. (1950). Childhood and society. W. W. Norton \& Company Inc., New York.

Estole (2018). Laro ng Lahi: Its importance in the inclusion to DepEd programs. In Prestoza, M. R., Paludipan, C. P., \& Abad, A. E. (2020). Perception of elementary school teachers on Laro ng Lahi in Quirino, Isabela. International Journal on Linguistics, Literature and Culture, 6(3), 1-8. Retrieved from

https://sloap.org/journals/index.ph p/ijllc/

Foley, P. (2008). Introduction. In J. Collins and P. Foley (Eds). 
Promoting children's wellbeing: Policy and practice. Bristol: Policy Press.

Hermans, R., Tondeur, J., Van Braak, J., \& Valcke, M. (2008). The impact of primary school teachers' educational beliefs on the classroom use of computers. Computers \& Education, 51(4), 1499-1509.

https://doi.org/10.1016/j.compedu .2008 .02 .001

Hotz, H. (2006). Introduction to game theory. Retrieved from http://www.theorie.physik.unimue nchen.de/lsfrey/teaching/archiv/so se_06/softmatter/talks/Heiko_Hot z-Spieltheorie-Handout.pdf.

Kafle, N. P. (2011). Hermeneutic phenomenological research method simplified. Bodhi: An Interdisciplinary Journal, 5 Kathmandu University, Nepal.

Khan, M. Z., Abbas, S. G., \&Zeb, R. (2018). The reasons for traditional games losing popularity: A case study of Skhy (Calf) in Nihagdara, KP (Pakistan). The Spark, 3(1), 129-142. Retrieved from https://core.ac.uk/download/pdf/2 87193016.pdf

King, D. A. (2004). The scientific impact of nations. Nature, 430(6997), 311-316.

https://doi.org/10.1038/430311a

Kneller, G. F. (1984). Movements of thought in modern education: Phenomenology. New York: John Wiley \& Sons, Inc.

Kolb, D. A. (1984). Experiential learning: Experience as the source of learning and development. New Jersey: Prentice Hall.

Kun, O. H., \& Mat Nayan, S. (2018). Jom Main! (Let's Play!): Promoting the values of Malaysia traditional children's games through the media. Media Literacy and Academic Research. Retrieved from https://www.mlar.sk/wp-
content/uploads/2019/12/3_Oh_H

ui_Kun.pdf

Lu, J. (2018). The 'Rules of War' are being broken: What exactly are they? Retrieved from https://www.npr.org/sections/goat sandsoda/2018/06/28/621112394/ the-rules-of-war-are-beingbroken-what-exactly-are-they

Magna Kultura (2012). The importance of preserving traditional games. In Prestoza, M. R., Paludipan, C. P., \& Abad, A. E. (2020). Perception of elementary school teachers on Laro ng Lahi in Quirino, Isabela. International Journal on Linguistics, Literature and Culture, 6(3), 1-8. Retrieved from https://sloap.org/journals/index.ph p/ijllc/

Mays, W., \& Brown, S. C. (1972). Linguistic analysis and phenomenology. London: Macmillan.

Miller, E., \& Kuhaneck, H. (2008). Children's perceptions of play experiences and play preferences: A qualitative study. American Journal of Occupational Therapy, 62(4), 407-415. https://doi.org/10.5014/ajot.62.4.4 07

Morales, M. P. E. (2017). Exploring Indigenous Game-based Physics Activities in Pre-Service Physics Teachers' Conceptual Change and Transformation of Epistemic Beliefs. Eurasia Journal of Mathematics, Science and Technology Education, 13(5), 1377 -

1409. https://doi.org/10.12973/eur asia.2017.00676a

Morales, M. (2014). Cultural and epistemological profile of Filipino learners. Electronic Journal of Science Education, 18(6).

Maryani, E., \& Syamsudin, H. (2009). Development of social studies learning programs to increase 
students' social skills competencies. Jurnal UPI EDU, 9(1).

Millington, W. H., \& Maxfield, B. L. (1906, July-September).

Philippine (Visayan)

Superstitions. The Journal of American Folklore, 19(74), 205211. Retrieved from http://www.jstor.org/stable/53456 7.

Piaget, J. (1962). Play, dreams and imitation in childhood. New York: W. W. Norton \& Company.

Prakash, N. (2012). ICT and women empowerment in a rural setting in India. In Globalization, technology diffusion and gender disparity: Social impacts of ICTs (pp. 15-24). IGI Global.

Prestoza, M. R., Paludipan, C. P., \& Abad, A. E. (2020). Perception of elementary school teachers on Laro ng Lahi in Quirino, Isabela. International Journal on Linguistics, Literature and Culture, 6(3), 1-8. Retrieved from https://sloap.org/journals/index.ph p/ijllc/

Salazar, Z. (2004). Kasaysayan ng Kapilipinuhan: Bagong Balangkas, Bagong Kasaysayan. In Villan, V. C., \& Esquejo, K. (2021). Pangangayaw: Ang pangingibang-bayan at paghahanap ng ginhawa sa kasaysayan at kalinangan Pilipino. Manila: ADHIKA ng Pilipinas, Inc.

Saputra, N. E., \& Ekawati, Y. N. (2017). Traditional games in improving children's basic abilities. Jurnal Psikologi Jambi, 2(2), 48-54. Retrieved from http://onlinejournal.unja.ac.id/jpj/article/view/ 4796.

Stone P. (2020). Destroying cultural heritage is an attack on humanity's past and present - it must be prevented. Retrieved from https://theconversation.com/destr oying-cultural-heritage-is-anattack-on-humanitys-past-andpresent-it-must-be-prevented$\underline{129412}$

Suhaebah, S. (2019). Traditional game as a social studies learning method to develop student's communication and collaborative skills. Presented during the $4^{\text {th }}$ International Seminar on Social Studies and History Education (ISSSHE) 2019 at Universitas Pendidikan Indonesia, Bandung, West Java, Indonesia.

UNAOC (2019). The United Nations Plan of Action to Safeguard Religious Sites. Retrieved from https://www.un.org/sg/sites/www. un.org.sg/files/atoms/files/12-092019-UNAOC-PoA-ReligiousSites.pdf

UNESCO (2018). Teacher's guide for incorporating traditional children's games in the classroom. Retrieved from http://www.unescobkk.org/filead min/user_upload/culture/ICHCG LPs/Full_Teachers_Guide.pdf.

Villan, V. C., \& Esquejo, K. (2021). Pangangayaw: Ang pangingibang-bayan at paghahanap ng ginhawa sa kasaysayan at kalinangan Pilipino. Manila: ADHIKA ng Pilipinas, Inc.

Vygotsky, L. S. (1966). Play and its role in the mental development of the child. Voprosy Psikhologii, 12, 6276.

Whiteman, S. (2005). Hopscotch: A history. Retrieved from https://www.albany.edu/ sw7656/

WHO (2018). Global recommendations on physical activity for health 5 17 years old. Retrieved from https://www.who.int/dietphysical activity/publications/physicalactivity-recommendations-5$\underline{17 \text { years.pdf?ua }=1}$ 